\title{
General Lexicography in Europe
}

\author{
Reinhard Rudolf Karl Hartmann, Dictionary Research Centre, \\ University of Exeter, Great Britain
}

\begin{abstract}
On the basis of several surveys of experts, centres and projects in lexicography, and against the author's own experience of metalexicography, the paper traces the recent progress of academic lexicography, especially in Europe. Particular attention is paid to 'dictionary research' in four of its divisions. One special concern is the professionalisation of the discipline in terms of conferences, publications and training initiatives.
\end{abstract}

Keywords: DICTIONARY RESEARCH, EUROPE, LEXICOGRAPHY, SURVEY

Opsomming: Algemene leksikografie in Europa. In hierdie artikel word die onlangse ontwikkeling van die akademiese leksikografie, veral in Europa, nagespoor aan die hand van verskeie ondersoeke uitgevoer deur leksikografiese kundiges, sentrums en projekte, en teen die agtergrond van die outeur se eie ervaring van die metaleksikografie. In die besonder word aandag geskenk aan "woordeboeknavorsing" in vier geografiese gebiede. Een saak waarop die aandag spesifiek gevestig word, is die verlening van professionele status aan die dissipline deur konferensies, publikasies en opleidingsinisiatiewe.

Sleutelwoorde: EUROPA, LEKSIKOGRAFIE, ONDERSOEK, WOORDEBOEKNAVORSING

\section{Introduction}

State-of-the-art surveys are as quickly (out)dated as they are initially useful, but to attempt them on a continental scale seems like the ultimate folly. Nevertheless, I am going to risk some generalisations about the European dictionary front in the hope that shared information is better than (merely) filed information.

Against the background of a survey of linguistics in Europe which I was asked to undertake over 20 years ago (Hartmann 1972) and a number of other fact-finding ventures since then (EURALEX congresses, cf. Hartmann 1984; Exeter D.R.C. bibliographical database and Who's Who directory; ERASMUS Consortium, cf. Hartmann 1992a), I sent out a questionnaire to all my main contacts to gather data for a lecture which I had originally intended for the 25th anniversary meeting of the Societas Linguistica Europaea (SLE) in 1991, but could not actually deliver until the inaugural conference of the European Society for the Study of English (ESSE) later that year. 
I asked such questions as "What would you estimate as the total number of dictionaries published since 1965", "What are the main dictionary types, in order of importance'?", and "Can you guess at the number of full-time lexicographers (in relation to the total population)?" (The questionnaire, completed by myself for the U.K., is reproduced in the Appendix. I gratefully acknowledge the help received by respondents). The replies I received were relatively incomplete, especially with respect to Eastern Europe where political changes have been momentous since 1991, but I relate them here in the context of other information 1 have in my files.

\section{Recent history}

Franz Josef Hausmann (1989) has remarked that "metalexicographical reflection is as old as lexicography itself" and cited the example of Paolo Beni and his critical review Anti-Crusca of 1612. Hausmann also has helpful things to say about the recent history of academic lexicography. For the period after World War II, he presents evidence for regarding the years between 1960 and 1970 as an important turning point, instanced by the pioneering conference at Bloomington, Indiana (1960) and the publication of Ladislav Zgusta's Manual of Lexicography (1971).

I find it intriguing that three other metalexicographers working in Europe have reached different conclusions about the start of contemporary lexicography, in their respective contributions to the International Encyclopedia of Lexicography, Wörterbücher/Dictionaries/Dictionnaires. Robert llson, in Article 199, calls 1968 a "momentous year" in British lexicography; Alain Rey, in Article 186, mentions several cases of a "reawakening" French lexicographic spirit in the period from 1950 to 1985; Herbert Emst Wiegand, in Article 206, states that for the post-war beginning of German lexicography, 1945 is "too early" and 1960 is "too late". What this suggests is that it would be unrealistic to assume a uniform rate of progress in European lexicography, at least in the post-war years to about 1970 .

Since the early 1970's it may be possible to stipulate a convergence of developments, due to a number of economic, sociological, educational and technological influences. There was economic prosperity, at least in Western Europe, which brought increased social mobility, more educational opportunities, better language teaching provision and more linguistic research at all levels, and the computer promised relief from mental drudgery. In lexicography, this produced new markets, new interests, new ideas, new investment. As we moved into the eighties, time seemed ripe for a boom.

If I was to highlight a single year, I would choose 1983, ten years ago, when a number of significant conferences were held at Newark (Delaware), Smolenice (Slovakia), Novi Sad (Yugoslavia), Augsburg and Aachen (Germany), and of course Exeter (U.K.) where the European Association for Lexi- 
cography (EURALEX) was founded, when the ambitious projects of the international encyclopedia Wörterbiucher/Dictionaries/Dictionnaires (3 volumes edited by Hausmann/Reichmann/Wiegand/Zgusta) and the double series of monographs (48 volumes published) and yearbooks ( 7 volumes published) under the general title Lexicographica were conceived, and when the European Science Foundation survey of lexicographical projects (Cignoni et al. 1983) was published.

\section{Lexicography in a European context}

I have already hinted at the difficulties of trying to build up a complete picture of the dictionary scene in Europe. One reason is that there have been few precedents for such surveys. The ESF survey mentioned above was limited to 114 scholarly dictionary projects in Western Europe, and Bernard Quemada's (1972) essay for the Current Trends in Linguistics series concentrated primarily on historical dictionaries, largely in Romance languages.

A second reason for the lack of information is the tension that still exists between academic lexicography and commercial dictionary production, with academics primarily interested in theoretical principles and dictionary publishers watching out tor market opportunities. In any case, most projects tend to operate within the confines of a particular dictionary tradition linked to the language, history and institutions of a country.

The third reason is that there are only a few centres, associations and periodicals through which projects and progress can be reported (the International Journal of Lexicography, which includes the EURALEX Newsletter, only started 5 years ago). Conferences have an important role to play in this respect, but as I have pointed out in one of my papers (Hartmann 1990a), we have a long way to go until the artificial barriers between universities, publishers and academies can be broken down.

For the purpose of presenting the data in this paper, I have divided them into four parts, (a) the three leading countries, (b) the rest of the European Community, (c) the countries outside the EC west of the former 'iron curtain', and $(d)$ the countries of Eastern Europe.

\section{"Les trois paysages"}

There are some good reasons for singling out the three largest countries of Europe in terms of population size (apart from Italy) for special treatment: Germany, France and the United Kingdom have long and distinguished lexicographical traditions, they are very productive both quantitatively and qualitatively, and many of the theoretical and practical innovations in recent years have come from them. That is why Hausmann (1985) speaks of "trois 
paysages", although he also characterises some of their differences: he praises the relatively well-developed "dictionary culture" in France, describes the British approach to "learners' dictionaries", and points out some inherent limitations of German lexicography.

There are established traditions and standards for the lexicography of the major languages, German, French and English, with 77,51 and 55 million native speakers respectively. The societies are effectively monoglot (admittedly with remarkable dialect differentiation), but there are also linguistic minorities of varying size and stability, e.g. Turkish and Sorbian in Germany, Arabic and Breton in France, and Urdu and Welsh in the United Kingdom.

We find comprehensive ranges of dictionary products, in terms of numbers and types. Wiegand has given the following estimates for Germany. in the period since about 1965:

\section{2,000 technical-terminological dictionaries, 100 dialect dictionaries, 80 spelling dictionaries \\ 70 general-explanatory dictionaries, \\ 30 dictionaries of foreign words, \\ 11 historical-etymological dictionaries.}

No figures are available for bilingual dictionaries, which I guess to be in the region of several hundred. Dictionary production in France and the United Kingdom appears to be more limited, and the distribution by types may be different, with (foreign) leamers' dictionaries forming an important genre in Britain (cf. Hartmann 1992b).

The three countries can boast strong publishing houses capable of delivering the goods, e.g. Duden and Langenscheidt in Germany, Le Robert and Larousse in France, Oxford and Collins in Britain. There are also sizeable bodies of working lexicographers, about 100 full-time in Germany and Britain and maybe fewer in France. Many of these have become members of EURALEX, and some regularly attend conferences in their own countries and elsewhere (some famous names from Germany: Drosdowski, Reichmann, Neubert; from France: Rey, Dubois, Gorcy; and from the U.K.: see Appendix).

There are periodicals and textbooks available, as follows: in Germany, Lexicographica (International Annual and Series Maior), Hausmann et al. (1989-91) and Schaeder (1987); in France, Lexique, Cahiers de Lexicologie, Quemada (1967) and Rey (1982); in Britain, the International Journal of Lexicography, McArthur (1986), Ilson (1986) and Sinclair (1987).

There are research centres, at least in embryo (particularly at Erlangen, Lille and Exeter), which may also exert a positive effect on the development of training (see below). Lexicography is occasionally linked to the study of the mother tongue (Institut für deutsche Sprache, Mannheim, Institut de la langue 
française, Nancy) or to Computational Linguistics (Bonn, Stuttgart, Birmingham).

Lest I give the impression that all is rosy in the European dictionary garden, I should frankly admit that there are a number of desiderata (cf. Hartmann 1986a) that have not yet been fulfilled even in the three leading countries:

- Complete, annotated lists of published dictionaries, by language, by information category, and by user group do not exist, and reliable production or sales statistics for the dictionary publishing industry are sadly lacking (for a bibliography of dictionary bibliographies, cf. Cop 1990), although according to one market report reference books now constitute over $15 \%$ of all books produced.

- Lists of ongoing dictionary projects, dictionary publishers and active lexicographers are not available, except for the rudimentary Who's Who directo ry database being assembled at Exeter.

- Job descriptions of required professional skills and accounts of on-thejob training schemes are hard to come by; one promising development is the elaboration of 'national vocational qualifications' for the (British) publishing industry, although not with the full backing of all dictionary publishers.

- A directory of relevant academic courses does not exist, although Wiegand (1989) gives a list of some of these involving aspects of dictionary research in German universities, and there are brochures about the European postgraduate Diploma in Lexicography (see below). It would be useful, too, to have a list of research topics treated at such centres as well as a catalogue of unpublished theses and dissertations.

[See also the relevant articles dealing with the monolingual and interlingual lexicography of German, French, English etc. in Hausmann et al. (1989-91).]

\section{The rest of the EC}

The remaining, currently 9, countries of the European Community include the three Benelux countries, Denmark, the Irish Republic, and the four southern countries Portugal, Spain, Italy and Greece, with two large language communities in terms of numbers of speakers ( 30 million for Italian and over $28 \mathrm{mil}$ lion for Spanish if non-standard dialects/languages like Lombardian, Sicilian, Catalan and Galician are counted separately), and the rest with fewer than 10 million each.

Dictionary production is much more limited in these countries (estimates for published dictionaries since 1965 include 500 for Italy, 200 for Denmark, 100 each for Spain and the Netherlands), as is the number of active lexicographers 
(one of the highest figures relative to population size, i.e. $50 / 5$ million, is claimed for Denmark, which has recently set up a professional association, Copenhagen having also hosted a series of 6 international Symposia since 1982).

Periodicals and other publications devoted to general lexicography are not so common in this group of countries (the Studi di lessicografia italiana are issued by the Accademia della Crusca in Florence; Marello 1989 is one of the few textbooks on bilingual lexicography; van Sterkenburg 1984 is a Dutch introduction to lexicography, Cabré and Lorente 1991 a bibliography of Catalan dictionaries, DANLEX Group 1987 a survey of computer applications to dictionary making).

Courses on aspects of lexicography are offered in Belgium (Universities of Liège and Gent, and at the M. Haps Terminology Institute at Brussels), Denmark (Arhus Business School has created a chair in Lexicography), and the Netherlands (INL at Leiden and Free University at Amsterdam). Some dictionary research is pursued at the above centres as well as in Ireland (Dublin), Italy (Pisa), Spain (Málaga, Barcelona, and Córdoba) and Greece (Thessaloniki). Because of the relative size and status of these languages vis-à-vis the 'big' European languages (German, French and English, e.g. as subjects taught in schools and universities, dictionaries for translation and other interlingual purposes are in greater demand here than in the relatively monoglot communities of Germany, France and the United Kingdom.

[See also the relevant articles dealing with the monolingual and interlingual lexicography of Danish, Dutch, Greek, Italian, Portuguese, Spanish etc. in Hausmann et al. (1989-91) and the EURALEX Congress proceedings (esp. Biblograf 1992).]

\section{Non-EC 'Western' Europe}

The next group, all except one in the European Free Trade Area and potential candidates for EC membership, include four Nordic and two Central European countries and one on the edge of the Middle East and Asia, a heterogeneous entity with little in common lexicographically, ranging from a prosperous island of 200,000 speakers of a single language to a relatively poor country with a population of over 50 million. I will venture only a few remarks about the lexicographic situation in these seven countries based on questionnaire returns.

In Norway, where the political and linguistic history was tied to that of Denmark for many centuries, the double standards of the literary bokmal and the colloquial Nynorsk have led to a high degree of language awareness, some deliberate language planning, and an active lexicographic community producing a wide range of bilingual-translation dictionaries, monolingual-spelling dictionaries, and normative-technical dictionaries. Courses are taught at Oslo 
University whose lexicographic centre under Dag Gundersen has also hosted the first conference of the new Nordic Lexicographic Association.

Iceland, the smallest country of Northern Europe, boasts a highly sophisticated literary tradition and good lexicographic output. Given the ratio of lexicographers per total population and the membership of its lexicographic society, Iceland outclasses the larger countries by a factor of 100 .

Sweden has a number of interesting dictionary projects linked to dialectology, computational linguistics and the teaching of Swedish to immigrants (e.g. at Göteborg and Lund), supported by the Swedish Academy. There is at least one textbook (Svensén 1987) used all over Scandinavia.

As in other countries of this group, bilingual dictionaries play an important role in Finland. However, relative to the number of Finnish native speakers (less than 5 million), lexicography is a lively activity, often in conjunction with language planning, translation and terminology work.

In the centre of Europe, the neutral countries Switzerland and Austria, with just under and over 7 million inhabitants, respectively, are concerned with documenting the various, mainly German, dialects (cf. Lurati and Stricker 1982); there is also some lexicographic interest at translator training and terminology centres (e.g. Infoterm in Vienna).

[See also the relevant articles dealing with the monolingual and interlingual lexicography of the Nordic Germanic languages, of Finnish, and Turkish (on which no other literature is available to me) etc. in Hausmann et al. (1989-91), and the ELRALEX Congress proceedings (esp. Snell-Hornby 1988 and Tommola et al. 1992).]

\section{Non-EC 'Eastern' Europe}

The last group in my survey are the countries of Eastern Europe, a region where we have seen many and rapid changes during the last few years. It is extremely difficult to keep up-to-date with developments, especially as far as the multiplying states of the former Soviet Union and Yugoslavia are concerned, since lexicographic information is rarely available and contacts are still limited.

Considering their relative population sizes (which range from over 150 million for Russia, through over 37 million for Poland and 20 million for Romania, to less than 3 million for Albania and under 2 million each for the Baltic States) and their weak economic superstructure, lexicographic research and production has a good record.

The Academies of Science (some of which are under review, or have been abolished recently) have promoted a long line of scholarly dictionary projects: historical dictionaries, etymological dictionaries; dialect dictionaries, idiom dictionaries and, just as important here as in the West, bilingual dictionaries for 
translation and foreign language learning. For Russia, one estimate for the number of dictionaries published since 1965 is 2,000.

From the wide range of anthologies, bibliographies and textbooks recently published (some may be difficult to obtain), I select the following: Dubichinskij et al. (1992, in Russian/Ukrainian), Kiefer et al. (1992, in English/French), Morkovkin and Trushinoj (1986, in Russian), Durco (1992, in Slovak/English), Filipec and Ćrmák (1985, in Czech), Miodunka (1989, in Polish).

[See also the relevant articles dealing with the monolingual and interlingual lexicography of the Slavonic languages (Russian, Polish, Czech, Bulgarian, Croatian etc.), Romanian, Hungarian, Estonian, Latvian, Lithuanian, Georgian, Albanian etc. in Hausmann et al. (1989-91), and the EURALEX Congress proceedings (esp. Magay and Zigány 1990 and Tommola et al. 1992).]

\section{Dictionary research in Europe today}

In this section 1 would like to widen the scope a little and discuss the status of lexicography in terms of dictionary making, dictionary research and professional training. There has indeed been a lively debate in the last ten years, especially in the context of EURALEX Congresses, as to whether lexicography has developed into a respectable field that deserves the title 'academic discipline', and what could or should be done to bridge the gulf between practical and theoretical lexicography.

The publication of Wörterbucher/Dictionaries/Dictionnaires. An International Encyclopedia of Lexicography (Hausmann et al. 1989-91) marks this move in the direction of a 'scientific activity'. To quote from Rufus Gouws's detailed review (1992: 290),

It is a prime example of the combination and interaction of a variety of methodological, didactic, linguistic and metalexicographic principles, and their practical application. It represents the state of the art of reference works by being encyclopedia, textbook, comprehensive bibliography and authoritative container of information.

1 usually distinguish four main aspects or branches of metalexicography or dictionary research: dictionary history, dictionary typology, dictionary criticism, and dictionary use, and I shall briefly illustrate them in the context of Europe.

As 1 have already mentioned, the lexicography of a country or language depends not only on the external history of that country or language, but also on the internal cultural traditions that evolve in successive generations of dictionary making. Thanks to such authorities as Gabriele Stein (1985) and Tom McArthur (1986), we now have an almost continuous account of the history of 
English lexicography. However, this is not a 'closed book': new knowledge comes to light all the time.

Thus, at a seminar on the subject of dictionary history (Hartmann 1986b), we heard Noel Osselton present evidence of a 16th-century dictionary compiler - Rawlinson - whose unpublished dictionary preceded and surpassed that of Robert Cawdrey who is normally regarded as the founder of the monolingual English dictionary. There had been other English dictionaries well before that, of course, as part of the interlingual Latinate tradition of Medieval and Renaissance Europe. At the same meeting, Nawal El-Badry speculated whether the fact that in bilingual lexicography (of English and Arabic) the passive or 'decoding' dictionary arrived before the active or 'encoding' dictionary can be generalised into a lexicographic universal.

Another fascinating branch of dictionary history revealed at the Exeter Seminar was called 'lexicographic archaeology' by Robert Ilson: showing connections between genealogically related dictionaries, e.g. tracing a recent British and a not so recent American dictionary via the Century Dictionary right back to the Imperial Dictionary, in tum a British adaptation of Noah Webster's American Dictionary. This is the kind of detective work that has led another contributor, Fredric Dolezal, to claim that the story of the English dictionary may actually be the story of a single edited and re-edited text!

Dictionary typology is concemed with the classification of the very different dictionary genres and profiles we find in various countries, periods, or cultures. The annual volumes which form one of the series of Lexicographica have attempted to highlight such dictionary types: the 'monolingual' dictionary in $1 / 1985$, the 'bilingual' dictionary in $2 / 1986$, the 'cultural' dictionary in $3 / 1987$, the 'computer-assisted' dictionary in $4 / 1988$, the 'LSP' dictionary in $5 / 1989$, and the 'etymological' dictionary in $7 / 1991$.

The type of dictionary in which I have myself taken some interest is the so-called leamer's dictionary. Most people specialising in English will be familiar with its prototypes, the Oxford Advanced Learner's Dictionary, the Longman Dictionary of Contemporary English, and the Collins COBUILD English Language Dictionary, and their minor imitators. There are comparable pedagogically oriented dictionaries for French on the market, but only one such monolingual dictionary has been designed for foreign learners of German; while lexicographers working on other languages have only just begun to experiment with this genre. Meanwhile, tensions have developed vis-à-vis the monolingual dictionary for native speakers, on the one hand, and the traditional bilingual dictionary for translators and foreign language learners, on the other. Combining features of both monolingual and interlingual lexicography, a compromise sub-type has emerged in, recent years, viz. the 'bilingualised learner's dictionary', in which translation equivalents are provided for each sense of each headword, an approach that has also yielded interesting results in other, e.g. onomasiological, dictionary types. 
Innovation may also come from another branch of dictionary research usually termed dictionary criticism, a relatively old field which has been bedevilled in the past by prejudice and arbitrary personal judgement. Several monographs in the Lexicographica Series Maior have not only shown, by detailed comparative text analysis, how idiosyncratic dictionary reviews can be, but also what might be done to work out more objective criteria for the evaluation and assessment of lexicographic output (cf. Hernández 1989 for Spanish, Ripfel 1989 for German, Jehle 1990 for English and French).

Dictionary use is the fourth branch of dictionary research or metalexicography. This allows us to find out by means of various empirical methods (interviews, tests, questionnaires, film and protocol analysis) what dictionary users actually do in the process of consulting the information presented in the dictionary.

The idea is not to guess what a particular reference work might be used for by its anonymous users, but to determine categorically for which tasks it has been found to be either beneficial or unsatisfactory. There have been quite a number of such interdisciplinary observational studies of different users of different dictionary types in different situational contexts, not just in Europe (cf. Hartmann 1989 for a review of the literature). Associated with the user perspective is the question of how dictionary users acquire the necessary reference skills, what these consist of, and how they can be taught deliberately. Some of the dictionary 'workbooks' now available for this purpose have been critically compared by a former M.A. student at Exeter (Stark 1990).

There are other topics apart from these four more widely publicised subjects of dictionary research. Some of these are covered in other volumes of the Lexicographica Series Maior and in articles contributed to the International Encyclopedia, notably interlingual lexicography, pedagogical lexicography, technical lexicography, and computational lexicography, all areas where there has been much progress in Europe. One particular area that does not yet appear to have an overall name, except perhaps for the concepts of 'macrostructure' and 'microstructure', covers the component structures of the dictionary, their interrelations, and the way they are put together in the successive stages of the lexicographic process. I can foresee, even predict, massive input and subsequent success in this specialised subject, but a lot will depend on the healthy interaction of theory and practice.

\section{Professional training}

Finally, a topic into which I have invested quite a lot of time during the last few years: how to raise standards by providing more and better training. We need to increase the public's awareness of lexicographic issues, and we need to teach dictionary users appropriate reference skills and how to improve them. Above all, we need to give the next generation of lexicographers a chance to do better, 
by looking at what has gone before (dictionary history), by appreciating the wide choice of genres available (dictionary typology), by elaborating criteria of assessing them (dictionary criticism), and by observing what goes on in the consultation process (dictionary use). At the same time, the practical side of dictionary making must not be ignored, in terms of field-work or recording (including text corpora), description or editing (including planning and resourcing), and presentation or publishing (including computer techniques).

For all these reasons I started in 1988 to negotiate with a number of representatives of dictionary research centres in various countries of Europe towards a training framework for lexicography, and with the help of an EC (ERASMUS) grant we managed to design a modular; interdisciplinary, multisite postgraduate programme at Diploma and Master's level which is now running at Exeter and at the same time at Lille III University in France and at the Free University Amsterdam in the Netherlands. The course at Exeter comprises the following components:

Principles and Practice of Dictionary Publishing,

Computing in Lexicography,

The Representation of Meaning in the Dictionary,

Typology and Component Structures of Dictionaries,

The User Perspective in Dictionary Research,

Bilingual Lexicography,

The Learner's Dictionary.

In addition, it includes a practical placement with a dictionary project and a dissertation as well as an optional ERASMUS exchange with students from Lille and Amsterdam. We are currently considering whether and how the course consortium could be extended to other centres in Europe.

\section{Conclusion}

My overall conclusion is that dictionary research is alive and well, and together with improved training facilities is likely to lead to further advances in dictionary making, although no single profile has yet emerged of the typical country, the typical dictionary, and the typical lexicographer in Europe. Quemada's statement (1972: 434) that "Lexicographic methodology has made great headway since the end of the last war" is even more valid today than two decades ago.

One caveat is perhaps in order as we reach the end of this continental conspectus. We should not be satisfied just with a knowledge about progress in Europe. A world perspective is now needed in lexicography just as in other spheres of human activity, and in this spirit $I$ join those who have attempted surveys of other scenes (Zgusta 1980, Algeo 1989, Hartmann 1990b, Hausmann 
et al. 1989-91, Delbridge 1992) in hoping for much widened lexicographic horizons.

\section{References}

Algeo, J. 1989. American Lexicography [Art. 200]. Hausmann, F.J. et al. (Eds.). 1990. Wörterbücher/Dictionaries/Dictionnaires. An International Encyclopedia of Lexicography (3 Volumes): 1987-2009. Berlin: W. de Gruyter.

Biblograf (Ed.). 1992. EURALEX '90 Proceedings. Actas del IV Congreso Internacional, Benalmádena (Málaga) 1990. Barcelona: Vox Biblograf.

Cabré, M.T. and M. Lorente. 1991. Els Diccionaris Catalans de 1940 a 1988 (Lexis 1). Bárcelona: Universitat de Barcelona.

Cignoni, L. et al. (Eds.). 1983. European Science Foundation Survey of Lexicographical Projects. Pisa: ILC.CNR.

Cop, M. 1990. Babel Unravelled. An Annotated World Bibliography of Dictionary Bibliographies, 16581988 (Lexicographica Series Maior 36). Tübingen: M. Niemeyer.

DANLEX Group. 1987. Descriptive Tools for Electronic Pracessing of Dictionary Data. Studies in Computational Lexicography (Lexicographica Series Maior 20). Tübingen: M. Niemeyer.

Delbridge, A. 1992. Lexicography in Australia. Lexikos 2: 63-72.

Dubich inskij, V.V. et al. (Eds.). 1992. Sovremennye problemy leksikografii. Sbormik nauchnykh trudov. Kharkov: KhLO.

Ďurčo, P. (Ed.). 1992. Bibliografia slovenskej idiomatiky, frazeológie a paremiolólgie. Bratislava: Komisia pre výskum frazeológie pri Slovenskom komitéte slavistov.

Filipec, J. and F. Cermák. 1985. Česká Lexikologie. Praha: Academia.

Gouws, R.H. 1992. Review of Hausmann et al. (Eds.). Wörterbücher/Dictionaries/Dictionnaires. Lexicographica International Annual 7/1991: 268-290.

Hartmann, R.R.K. 1972. The Organization of Linguistics in Western Europe. Sebeok, T.A. (Ed.). 1972. Current Trends in Linguistics. Vol. 9: 1795-1818. The Hague: Mouton.

Hartmann, R.R.K. (Ed.). 1984. LEXeter '83 Proceedings. Papers from the International Conference on Lexicography at Exeter 1983 (Lexicographica Series Maior 1). Tübingen: M. Niemeyer.

Hartmann, R.R.K. 1986a. The Training and Professional Development of Lexicographers in the UK. Ilson, R. (Ed.). 1986 Lexicography. An Emerging Internalional Profession: 82-92. Manchester: U.P.

Hartmann, R.R.K. (Ed.). 1986b. The History of Lexicography. Papers from the D.R.C Seminar at Exeter 1986 (Amsterdam Studies in the Theory and History of Linguistic Science 1ll.40). Amsterdam: J. Benjamins.

Hartmann, R.R.K. 1989. Sociology of the Dictionary User: Hypotheses and Empirical Studies [Art. 12]. Hausmann, F.J. et al. (Eds.). 1989. Wörterbücher/Dictionaries/Dictionnaires. An Intemational Encyclopedia of Lexicography (3 Volumes): 102-111. Berlin: W. de Gruyter.

Hartmann, R.R.K. 1990a. A Quarter of a Century's Lexicographical Conferences. Magay, T. and J. Zigány (Eds.). 1990. BudalEX '88 Proceedings. Pajers from the 3rd International EURALEX Congress, Budapest 1988: 569-575. Budapest: Akadémiai Kiadó. 
Hartmann, R.R.K. (Ed.). 1990b. Lexicography in Africa. Progress Reports from the D.R.C. Workshop at Exeter 1989. Exeter: U.P.

Hartmann, R.R.K. 1992a. Training in Lexicography - The Exeter ERASMUS Initiative. Biblograf (Ed.). 1992. EURALEX '90 Proceedings. Actas del IV Congreso Internacional, Benalmadene (Málaga) 1990: 527-532. Barcelona: Vox Biblograf.

Hartmann, R.R.K. 1992b. Lexicography, with Particular Reference to English Learners' Dictionaries. Language Teaching 25,3: 151-159.

Hausmann, F.J. 1985. Trois paysages dictionnairiques: La Grande-Bretagne, la France et l'Allemagne. Lexicographica: International Annual for Lexicography 1:24-50.

Hausmann, F.J. 1989. Kleine Weltgeschichte der Metalexikographie. Wiegand, H.E. (Ed.). Wörterbücher in der Diskussion (Lexicographica Series Maior 27). 1989. Tübingen: $M$. Niemeyer 75-109.

Hausmann, F.J. et al. (Eds.). 1989-91. Wörterbücher/Dictionaries/Dictionnaires. An International Encyclopedia of Lexicography ( 3 Volumes). Berlin: W. de Gruyter.

Hernández, H. 1989. Los diccionarios de orientación escolar. Contribución al estudio de la lexicografin monolingüe española (Lexicographica Series Maior 28). Tübingen: M. Niemeyer.

Ilson, R. (Ed.). 1986. Lexicography. An Emerging Intermational Profession. Manchester: U.P.

nson, R. 1990. Present-Day British Lexicography. Hausmann, F.J. et al. (Eds.). 1990. Wörterbücher/Dictionaries/Dictionnaires. An International Encyclopedia of Lexicography (3 Volumes): 1967-1983. Berlin: W. de Gruyter.

Jehle, G. 1990. Das englische und französische Lemerwörterbuch in der Rezension. Theorie und Praxis der Wönterbuchkritik (Lexicographica Series Maior 30). Tübingen: M. Niemeyer.

Kiefer, F. et al. (Eds.). 1992. Papers in Computational Lexicography (2nd COMPLEX Conference, Budapest 1992). Budapest: Linguistics Institute, Hungarian Academy of Sciences.

Lurati, O. and H. Stricker (Eds.). 1982. Die schweizerischen Wörterbücher. 4. Kolloquium der Schweiz. Geisteswissenschafliche Gesellschaft 1979. Fribourg: Editions Universitaires.

Magay, T. and J. Zigány (Eds.). 1990. BudaLEX '88 Proceedings. Papers from the 3rd International EURALEX Congress, Budapest 1988. Budapest: Akadémiai Kiad6.

Marello, C. 1989. Dizionari bilingui con schede sui dizionan italiani per francese, inglese, spagnolo, tedesco (Fenomeni Linguistici 6). Bologna: Zanichelli.

McArthur, T. 1986. Worlds of Reference. Lexicography, Learning and Language from the Clay Tablet to the Computer. Cambridge: U.P.

Miodunka, W. 1989. Podstawy leksykologii i leksykografii. Warszawa: PWN.

Morkovkin, V.V. and L.B. Trushinoj. 1986. Uchebniki i slovari $v$ sisteme sredstv obuchenija russkomu jazyku kak inost rannomu. Sbornik statej. Moscow: Russkij Jazyk.

Quemada, B. 1967. Les dictionnaires du français moderne (1535-1863). Etude sur leur histoire, leurs types et leurs méthodes. Paris: Didier.

Quemada, B. 1972. Lexicology and Lexicography. Sebeok, T.A. (Ed.). 1972. Current Trends in Linguistics 9: 395-475. The Hague: Mouton.

Rey, A. 1982. Diclionnaires et encyclopédies (Que sais.je? 200). Panis: P.U.F.

Rey, A. 1990. La lexicographie française depuis Littré. Hausmann, F.J. et al. (Eds.). 1990. Wönterbücher/Dictionaries/Dictionnaires. An Intemational Encyclopedia of Lexicography (3 Volumes): 1818-1843. Berlin: W. de Gruyter. 
Ripfel, M. 1989. Wörtertuchkritik. Eine empirische Analyse won Wörterbuchrezensionen (Lexicographica Series Maior 29). Tübingen: M. Niemeyer.

Schaeder, B. 1987. Germanistische Lexikggraphie (Lexicographica Series Maior 21). Tübingen: $M$. Niemeyer.

Sinclair, J.M. (Ed.). 1987. Looking Up. An Account of the COBUILD Project in Lexical Computing. London and Glasgow: Collins.

Snell-Hornby, M. (Ed.). 1988. ZüriLEX'86 Proceedings. Papers Read at the EURALEX Intemational Congress, Zürich 1986. Tübingen: A. Francke.

Stark, M. 1990. Dictioniary Workbooks. A Critical Evaluation of Dictionary Workbooks for the Foreign Language Learner (Exeter Linguistic Studies 16). Exeter: U.P.

Stein, G. 1985. The English Dictionary before Cawdrey (Lexicographica Series Maior 9). Tübingen: M. Niemeyer.

Svensén, B. 1987. Handbak i lexikografi. Pnnciper och metoder'i ordbaksarbetet. Stackholm: TNC.

Tommola, H. et al. (Eds.). 1992. EURALEX '92 Proceedings. Papers Submitted to the Sth EURALEX International Congress, Tampere 1992 (Studia Translatologia A.2, 2 volumes). Tampere: U.P.

Van Sterkenburg, P.G.J. 1984. Van woordenlijst tot woordenboek. Leiden: E.J. Brill.

Wiegand, H.E. 1989. Der gegenwärtige Status der Lexikographie [Art. 29]. Hausmann, F.]. et al. (Eds.). 1989. Wörterbücher/Dictionaries/Dictionnaires. An International Encyclopedia of Lexicography (3 Volumes): 246-280. Berlin: W. de Gruyter.

Wiegand, H.E. 1990. Die deutsche Lexikographie der Gegenwart. Hausmann, F.J. et al. (Eds.). 1990. Wörterbücher/Dictionaries/Dictionnaires. An International Encyclopedia of Lexicography (3 Volumes): 2100-2246. Berlin: W. de Gruyter.

Zgusta, L. 1971. Menual of Lexicography. The Hague: Mouton.

Zgust,, L. (Ed.). 1980. Theory and Method in Lexicography: Western and Non-Western Perspectives. Columbus SC: Hornheam Press. 


\section{Appendix}

\begin{tabular}{|c|c|c|}
\hline Lexicography in Europe 1991 & Return to: & $\begin{array}{l}\text { R. Hartmann } \\
\text { Dictionary Research Centre } \\
\text { University of Exeter } \\
\text { EX4 4QH Great Britain }\end{array}$ \\
\hline
\end{tabular}

Country

U.K. Language(s) English, Welsh (etc.)

Informant R. Hartmann

\section{Background}

1. Mention one or two features that have influenced or dominated the lexicographic tradition in your country (e.g. bilingualism in Belgium, diglossia in Greece):

Largely monoglat society (English), with regional and social dialects. English as a foreign language taught widely. Minority languages (Welsh, Scots, Hindi) cannot compete with English, the medium of instruction at all levels of education.

2. Are there any traditional views of language that may have affected the development of native-speaker oriented dictionaries?

Usage not regulated by academies of any kind, but a 'purist' strand produced 'hard word' dictionaries (17th and 18th century).

3. Are you aware of any industrial, political or technological foundations that underpin current lexicographic production?

Scholarly lexicogmaphy (dictionaries of classical languages, dialect and historical dictionaries) underfunded in relation to commercial general-purpose dictionary-making. Computers beginning to have an impact, e.g. on text corpora.

\section{Professional data}

4. Can you make a guess at the number of full-time lexicographers (in relation to the total population)?

About 75 (56 million)

5. What would you estimate as the total number of dictionaries published since 1965 ?

About 1000

6. What are the main dictionary types, in order of importance?

(Give examples of prototypes)

historical-etymological dictionaries general-explanatory dictionaries technical-terminological dictionaries (foreign) leamer's dictionaries dialect dictionaries bilingual dictionaries other thesaurus idiom dictionaries
(Oxford English Dictionary) (Concise Oxford Dictionary) (Macmillan [various])

(Advanced learners' Dic.)

(Wright)

(Collins [various])

(Roget's)

(Manser) 


\section{Professional development}

7. Name some of the leading lexicographers in your country.

J. Aitken, R. Allen, S. Atkins, I. Ayto, A. Cowie, G. Fox, S. Greenbaum, P. Hanks, M. Hardcastle, R. llson, E. Kirkpatrick, M. Manser, T. McArthur, R. Moon, N. Osselton, P. Proctor, R. Quirk, A. Room, M. Rundell, J. Sager, I. Simpson, J. Sinclair, C.C. Smith, D. Summers, E. Weiner, J. Wells, J. Whitcut

8. Which are the main centres of dictionary research?

Exeter, London, Leeds, Oxford, Birmingham

9. Are there any academic courses in lexicography, apart from on-the-job vocational training offered by publishers?

Exeter University Annual International Lexicography Course (short-lerm)

Exeter University Dip./M.A. Course in Lexicography (one-year)

UMIST (Manchester)

Birmingham University

\section{Publications}

10. Are there any periodicals devoted to lexicography?

Intemational Joumal of Lexicography (Oxford)

11. Suggest one or two titles of basic textbooks published in your country recently.

R.R.K. Hartmann Lexicography, Principles and Practice London: Academic Press 1983

R. Ilson Lexicography, An Emerging Intema tional Profession Manchester UP 1986 M. Stork Dictionary Workbook Exeter UP 1990

12. Please provide bibliographical references of basic survey articles/reports.

A.I. Aitken (1990) "The Lexicography of Scots" (Ant. 199a) \&

R. Ison (1990) "Present Day British Lexicography" (Art. 199) in Hausmann et al.

Wörterbücher/Intermational Encyclopedia of Lexicography Berlin: W. de Gruyter pp. 1967-1983 